\section{June meetings}

5 June 1985, Seminar on Laboratory Automation, London, UK (Marketing Director, V.A. Howe \& Co., 12-14 St Anne's Crescent, London SW18 2LS, UK) 10-15 June 1985, Bari International Conference on F.VIII/von Willebrand Factor-Biological and Clinical Advances, Pizzomunno Vieste del Gargano, Italy (Dr N. Ciavarella, Hemophilia Centre, Policlinico, University, 70124 Bari, Italy) 25-28 June 1985, International Symposium on Forest Utilization of Municipal and Industrial Wastewater and Sludge, Seattle, Washington, USA (K. Grier, College of Forest Resources AR-10, University of Washington, Seattle, WA 98195)

\section{August meetings}

24-27 August 1985, International Conference on the Immonogenetics of Type I Diabetics and Autoimmune Thyroid Disease, St. John's, Newfoundland, Canada (N.R. Farid, Prof. of Medicine, Chief-Division of Endocrinology and Metabolism, Memorial University of Newfoundland, St John's, Newfoundland, Canada)

\section{September meetings}

2-6 September 1985, International Conference on Atmospheric Carbon Dioxide; Its Sources, Sinks and Global Transport, Kandersteg, Switzerland (Ulrich Siegenthaler, Physics Institute, Sidlerstrasse 5, CH-3012 Bern, Switzerland)

16-19 September 1985, European Congress for Artificial Organs, Athens, Greece (Prof. S. Raptis, M.D. P.O. Box 14127, 11510 Athens, Greece)

16-20 September 1985, International Meeting on Quantum Chemistry, Strasbourg, France (Dr A. Veillard, Université Louis Pasteur, Institut Le Bel, 4 Rue Blaise Pascal, 67000 Strasbourg, France).

17-19 September 1985, International Symposium on Lyme Disease and Related Disorders, Vienna, Austria (Dr G. Stanek, M.D. Hygiene Institute of the University, A-1095 Vienna, Austria).

30 September-3 October 1985, European Symposium on Hormones and Cell Regulation, Strasbourg, France (Dr R.J.B. King, Imperial Cancer Research Fund Laboratories, Hormone Biochemistry Department, PO Box 123, Lincoln's Inn Fields, London WC2A 3PX, UK).

\section{October meetings}

3-4 October 1985, International Meeting on Haemodynamics and Atherosclerosis, Wellington, New Zealand (Dr W.E. Stehbens, Department of Pathology, Wellington Clinical School of Medicine, Wellington, 2, New Zealand).

3-5 October 1985, 2nd Congress of the European Society of Magnetic Resonance in Medicine and Biology (with Exhibition), Montreux, Switzerland (Dr M.A. Hopf, 1 route de Florissant $\mathrm{CH}-1206$ Geneva, Switzerland)
8-10 October 1985, International Congress and Exhibition for Biotechnology, "Biotechnica", Hannover, West Germany (Deutsche Messe - und Ausstellungs AG, Messegelande, D-3000, Hannover 82, FRG).

20-25 October 1985, International Conference on Leukotrienes and Prostanoids in Health and Disease, Jerusalem, Israel (Prof. U. Zor, Dept. of Hormone Research, Weizmann Institute of Science, Rehovot, Israel 76100)

21-24 October 1985, International Conference on Pesticides Toxicity, Safety and Risk Assessment, Lucknow, India (Dr T.S.S. Dikshith, General Secretary of the Industrial Toxicology Research Centre, Mahatma Gandhi Marg, Post Box No. 80, Lucknow - 226001, India).

23-25 October 1985, Congress of the International Society for Research on Civilization Diseases and Environment, Budapest, Hungary (Congress Bureau MOTESZ, Budapest PO Box 32, H-i1361, Hungary). 28 October-1 November 1985, International Symposium on Source Term Evaluation for Accident Conditions, Columbus Ohio, USA (M. Jankowski, Div. of Nuclear Safety, c/o Int. Atomic Energy Agency, Vienna International Centre, PO Box 100, A-1400 Vienna, Austria).

\section{November meetings}

18-21 November 1985, Scientific Consensus Conference on methods for assessment of the cariogenic potential of foods, Texas, USA (Dr Dominick P. DePaola, Chairman Consensus Conference Planning Committee, Dean, U.T.H.S.C.S.A., DS 7703 Floyd Curl Drive Antonio, Texas 78284, USA)

25 November-6 December 1985, International Symposium on Optical and Electro-Optical Applied Science and Engineering, Cannes, France (J. Prado, Cannes Conference Coordinator, ANRTAssociation Nationale de la recherche Technique 101, Avenue Raymond Poincaré, 75116 Paris, France)

\section{Appointments}

President Reagan has announced his intention to nominate Dr John H. Moore as Deputy Director of the National Science Foundation (NSF). Dr. Moore has been Associate Director and Senior Fellow of the National Science Board, the policy making body of NSF since 1982. Dr Moore would succeed Donald Newton Langenberg.

The Minister of Agriculture, Fisheries and Food has appointed Dr Robert $N$. Crossett, Chief Scientist (Fisheries and Food) of the Ministry, to be a member of the Agricultural and Food Research Council.

Please send 'Announcements' entries to: The Editor, Nature, 4, Little Essex Street, London WC2R 3LF, UK
The KROC Foundation has endowed a \$1 million chair at UC-San Francisco to support biomedical research on rheumatic and other immunological diseases. The first holder of the Robert L. Kroc Chair in Rheumatic and Connective Tissue Diseases is Edward J. Goetzl, professor of medicine and director of the Division of Allergy and Immunology at UCSF.

Weizmann Institute chemist Professor Zippora Shakked has been named first incumbent of the Helena Rubinstein Chair in Structural Biology. Prof Shakked is a member of the Institute's Department of Structural Chemistry, applying X-ray crystallography methods to investigate compounds responsible for the expression of inherited traits.

Professor J. MacMillan, Professor of Organic Chemistry in the University of Bristol, has been appointed as Alfred Capper Pass Professor of Organic Chemistry in succession to Professor Whiting, who is retiring. Professor Whiting will be reengaged part-time, as Professor of Organic Chemistry.

Dr J.D. Baum has been appointed to Bristol University's Chair in Child Health upon the retirement of Professor N.R. Butler at the end of July 1985.

Dr J.P. McGeehan, Senior Lecturer in Communications Engineering at the University of Bath, has been appointed to Bristol University's Chair in Communications Engineering.

Dr J.W.B. Bradfield, Consultant Senior Lecturer in Pathology at the University of Bristol, has been appointed to Bristol University's Chair in Histopathology.

\section{Awards}

The National Science Foundation is offering awards to women scientists and engineers wishing to become visiting professors at US academic institutions. Awards may range from one academic term to 24 months, full or part time, with the usual period being one year. For terms of eligibility and further information write to Visiting Professorships for Women Program, National Science Foundation, Washington, DC 20550

\section{Miscellaneous}

The University of Essex is to offer the UK's first MSc Course in Aerosol Science and Technology from October this year. The one-year course will teach the theoretical and practical aspects of aerosol science and technology with specialist options in atmospheric chemistry and aerosols, and the physics of aerosols. For further information contact Irene Lally, Information Officer, University of Essex, Wivenhoe Park, Colchester, Essex. 